\title{
Plasma exosomes impact on paracrine secretion of peripheral blood mononuclear cells in patients with chronic heart failure
}

\author{
L.V. Natrus' ${ }^{1}$, P.F. Muzychenko ${ }^{1}$, D.O. Labudzynskyi ${ }^{2}$, P.A. Chernovol ${ }^{1}$, Y.G. Klys ${ }^{1}$ \\ ${ }^{1}$ Bogomolets National Medical University, Kyiv; \\ 2 Palladin Institute of Biochemistry of National Academy of Science of Ukraine, Kyiv; \\ e-mail:Lnatrus777@gmail.com
}

The study of the exosomal effect on the paracrine secretion of peripheral blood mononuclear cells of patients with chronic heart failure (CHF) in vitro demonstrated gender-associated changes in the synthesis and secretion of the key factors of endothelial inflammation by leukocytes. Under the exosomesinfluence, the synthesis and accumulation of the cytokine monocyte chemoattractant protein-1 (MCP-1) in the leukocytes of healthy donorsincreased by $26 \%$; while in women by $18 \%$, in men by $38 \%$ was observed. Incubation of patients'cells with suspension of exosomes increased intracellular synthesis of MCP-1 in women by 16\%, in men by 19\%.Interestingly, in activated cells of control women group the synthesis of MCP-1 under the exosomes influence was 2.7 times higher than in the group of female patients and in leukocytes of male donors 4 times higher than in the CHFmale group. Thus, under the exosomes influence the synthesis of the cytokine MCP-1 in cells increaseswhereasits paracrine secretion decreases, which may be considered as one of the potential physiological mechanisms of "restraining" the progress of inflammation. Our findings suggest that the level of cytokinetumor necrosis factor-alpha (TNFa) synthesis in activated leukocytes of CHF and control groups was almost the same, while in CHF group the TNFa level increases only in the culture medium. Incubation with exosomes did not cause significant changes in cytokine production, but in the CHF group there was a tendency to decrease the "medium/cell" index by more than 1.3 times. Subsequent future studies of the exosomal corrective effects would enable to establish algorithms for potential therapeutic solutions on initiative mechanisms of endothelial inflammation and development of acute and chronic ischemia. Our primary experimental work demonstrates the need for further study of the exosome's influence on peripheral blood leukocyte function both in vitro and in vivo experimental models. Key words: exosomes, chronic heart failure, MCP-1,TNF $\alpha$, paracrine secretion, genderassociated differences.

\section{INTRODUCTION}

Nowadays the prospect of cytokine correction during chronic inflammatory processes, control of cell proliferation, the influence of transplant cells, etc. are the main reasons for active research inthe mechanisms of controlled paracrine secretion by both mesenchymal stem cells and peripheral blood mononuclear cells (PBMC). It is believed, that the lion's share of cytokines produced by PBMC cells paracrinely have a pronounced pro-inflammatory, antiapoptotic, proregenerative effect [1].
Significant influence on the mechanisms of paracrine secretion can have microenvironment and exogenous factors, including exosomes. Currently, the physiological significance of liposome-like regulatory vesicles - exosomes (Exos) remains poorly understood. For this reason the peculiarities of exosome formation by donor cells, the qualitative difference in their content and the mechanisms of their regulatory influence are being actively studied. One recent study suggests, that the formation of exosomes should be considered as the removal of donor cells from unnecessary components to

(C) 1.V. Natrus, P.F. Muzychenko, D.O. Labudzynskyi, P.A. Chernovol, Y.G. Klys 
maintain cellular homeostasis [2]. However, the dominant opinion is that exosomes are formed not by chance and play an important role in intercellular communication, are able to carry out paracrine regulation directly affecting the molecular processes of cellular signaling. The reason is that these extracellular vesicles contain a huge number of different regulatory molecules: nucleic acids (microRNA, long-coding RNA, ribozymes, intact and mutated mRNA, DNA fragments), lipids and lipoproteins, metabolites, etc. $[3,4]$.Considering the high bioavailability of exosomes in the biological fluids of patients and healthy donors, the current direction in development of biomarkers or potential DNA/ RNA material transporters based on exosomes is very promising for the future [5]. Thus, analysis of cell-free DNA concentration (cfDNA) in blood plasma showed, that more than $93 \%$ of cfDNA in blood plasma is in the composition of exosomes. When the blood sample is stored, the number of exosomes and the concentration of exosomal DNA in the plasma sample increases. Since the release of exosomes from cells is an energy-dependent process, its direction probably makes significant biological sense [6].

Guided by the high novelty of research in this area, it became relevant to investigate the features of paracrine secretion of PBMC cells in patients with chronic heart failure (CHF) under the action of isolated from the blood plasma of healthy donorsexosomes in vitro. It is important to discuss a number of methodological ways of exosomes morphological verification and their molecular identification. Our research results may be useful for further study of paracrine signaling of blood mononuclear cells, as well as the corrective effect as a potential therapeutic influenceon cardiovascular disease. Two key markers of inflammatory cytokines were selected for the panel: Tumor necrosis factoralpha (TNF $\alpha)$ and Monocyte Chemoattractant Protein (MCP-1). In view of the ambiguity of the public data about the role of TNF $\alpha$ and MCP-1 in the progress of endothelial dysfunction and its therapeutic correction $[7,8]$, especially in the context of gender-related differences, makes it very promising to study exosomal influence on the PBCM primary culture of CHF patients. Thus, the aim of the study was to investigate the exosomes effect of healthy donors on the paracrine secretion of peripheral blood mononuclear cells of healthy people and patients with CHFin vitro considering gender-associated features.

\section{METHODS}

The design of our study and the main methodological steps are shown (Fig. 1). Briefly, in block diagram: biomaterial for the study was obtained from patients in a cardiac department and healthy donors. Exosomes were taken from the plasma of healthy donors. After $24 \mathrm{~h}$ of cultivation with LPS (leukocyte activation), a suspension of exosomes was added to the PBMC medium for further incubation during the day. Studies of cells cytokine secretion by ELISA were performed in the following biomaterial of subjects: 1) the culture medium of control PBMC; 2) lysate PBMC without exosomes; 3) culture medium on the background of incubation of PBMC with exosomes; 4) lysate PBMC after incubation with exosomes; 5) serum of venous blood. Morphological verification of exosomes was performed by electron microscope.

Survey samples. Collected venous blood under fasted conditions in vacuum EDTA tubes was used for the study. The experimental group "PAT" $(n=15)$ consisted of patients fromcardiac department with CHF, who had suffered a myocardial infarction in the last 5 years. The control group $(n=14)$ consisted of young, relatively healthy volunteers, who were selected on the basis of examination, survey and the results of biochemical and hematological blood tests. All gave permission (in the form of written informed consent) for the use of biomaterial for research (report № 128 dated 23.12.2019 of the Commission on Bioethics of Bogomolets National Medical University). There were 8 (57\%) men in the Control group and $8(53 \%)$ men in the PAT group. The age group differed 
Me, (Max-Min): PAT 77.5 (55-87) years; Control $26(19-48)$ years.

PBMC isolationand cultivation. Patients' blood was diluted (1:1) with standard phosphate buffer (PBS), centrifuged in a Ficoll gradient from the Ficoll-Paque PLUS (Ficoll-Paque TM, GE Healthcare, Sweden) in a ratio of 3:4 at $400 \mathrm{~g}, 25 \mathrm{~min}$ at $18^{\circ} \mathrm{C}$. The cell precipitatewas collected and washed with cold $\mathrm{Ca}^{2+} / \mathrm{Mg}^{2+}$ free PBS and then prepared for cultivation. Cells were cultured in Roswell Park Memorial Institute medium -RPMI-1640 ("Sigma-Aldrich", USA) supplemented with 5\% FCS ("Gibco ${ }^{\circledR}$ Invitrogen”, USA), 1\% penicillin/streptomycin and $1 \%$ L-glutamine ("Sigma-Aldrich", USA) at $37^{\circ} \mathrm{C}$ and $5 \% \mathrm{CO}_{2}[9,10]$. After $24 \mathrm{~h}$ of $50 \mathrm{ng} /$ ml LPS (Fermentas) activation the cells were incubated for $24 \mathrm{~h}$ with an extract of exosomes from the plasma of healthy donors.

Isolation and verification of exosomes. Exosomes were isolated from the plasma of control group individuals using the Total Exosome isolation kit ("Invitrogen", USA) according to the manufacturer's protocol. The principle of exosome isolation lies in the fact, that by binding water molecules the total isolating reagent of the exosome displaces less soluble components from the solution, in particular vesicles. This allows them to be collected by centrifugation. After 30 min incubation with the reagent at $2-8^{\circ} \mathrm{C}$, the suspension with exosomes was precipitated by centrifugation at $10,000 \mathrm{~g}$ for $5 \mathrm{~min}$ at room temperature. The resulting precipitate of exosomes was carefully resuspended in sterile PBS buffer. Production of lysates for the determination of cytokines by ELISA. Cultivation medium (M) was selected after daily incubation and stored $\left(-20^{\circ} \mathrm{C}\right)$, while PBMC cells were lysed in RIPA buffer [11] at $+4^{\circ} \mathrm{C}$. The protein concentration in the samples was determined on a semi-automatic biochemical analyzer BS-3000M (China), using a biochemical kit "Diagnosicum Zrt" (Hungary). The content of interleukins in blood serum, M and CL samples was determined by ELISA us-

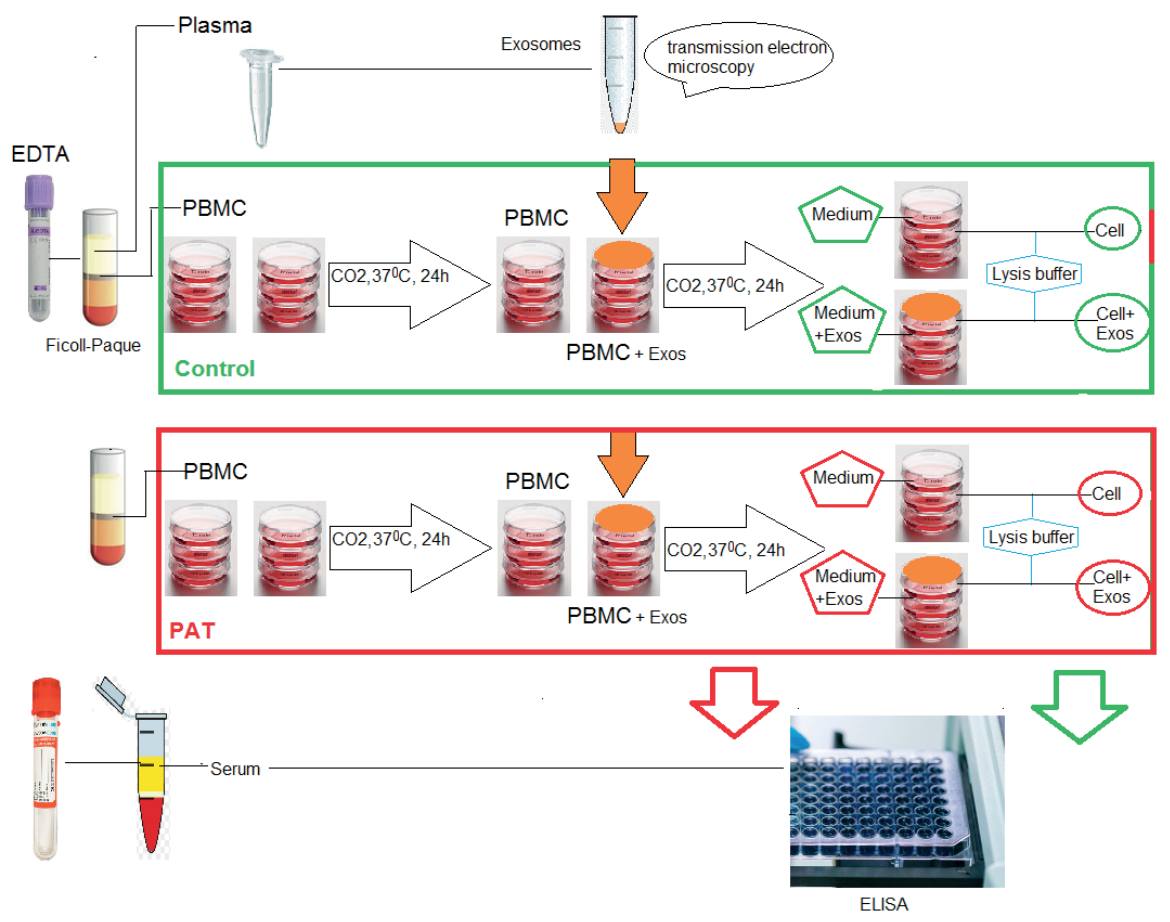

Fig. 1. Design scheme of the study, which was conducted on PBMC cells of CHF patients (PAT) and healthy volunteers (Control). PBMC - peripheral blood mononuclear cells, Exos - a mixture of exosomes; Medium (M) - PBMC culture medium; Cell lysates - cellular extracts after incubation 
ing an analyzer RT-2100C (China), using test systems "Vector-Best".

Statistical analysisof the data was performed using IBM SPSS Statistics 23 and MedStat. The distribution was checked using the Shapiro-Wilk test. Most of the parameters did not reflect the normal distribution, so we used nonparametric criteria: Kruskal-Wallis.For pairwise comparison we used the Dunn or Mann-Whitney test, taking into account the Bonferoni corrections. $\mathrm{P}$-values and 95\% confidence interval (CI) were also calculated.

\section{RESULTS AND DISCUSSION}

Our experimental work was designed in the focus of using a commercial kit for exosome isolation, which, according to the available data [4], made it possible to isolate these microvesicules with the highest efficiency. Certainly, we cannot exclude the possible influence of the reagents of the isolation kit on the chemical and mechanical properties of Exo lipid bilayers, but we emphasize that one way or another during the experiment we studied the regulatory effects of the exosomal bioactive molecules that are contained within these vesicular structures and acted on PBMC cell culture.

All $\mathrm{M}$ and Cell samples were standardized and listed for protein concentration (mg/ $\mathrm{ml}$ ) before interleukin determination. Analysis of the cytokines content in Medium and Cell samples showed a significant discrepancy in both groups (Fig. 2). Activated leukocytes in Medium samples from healthy donors secreted cytokines TNF $\alpha$ and MCP-1 in the range of $328-405 \mathrm{pg} / \mathrm{ml}$ protein. Medium samples from the PAT group showed an insignificant increase in TNF $\alpha$ secretion (by $25 \%$ ) and a decrease in MCP-1 (by 20\%) relative to the control group. The difference in indicators was at the level of $\mathrm{P}>0.05$, probably due to the small number of people in the groups and significant CI. Incubation of PBMC in the presence of exosomes did not reveal a significant difference in the secretion of these cytokines in both groups.

In Cell samples after cultivation $(24 \mathrm{~h})$, the content of cytokines TNF $\alpha$ and MCP-1 differed
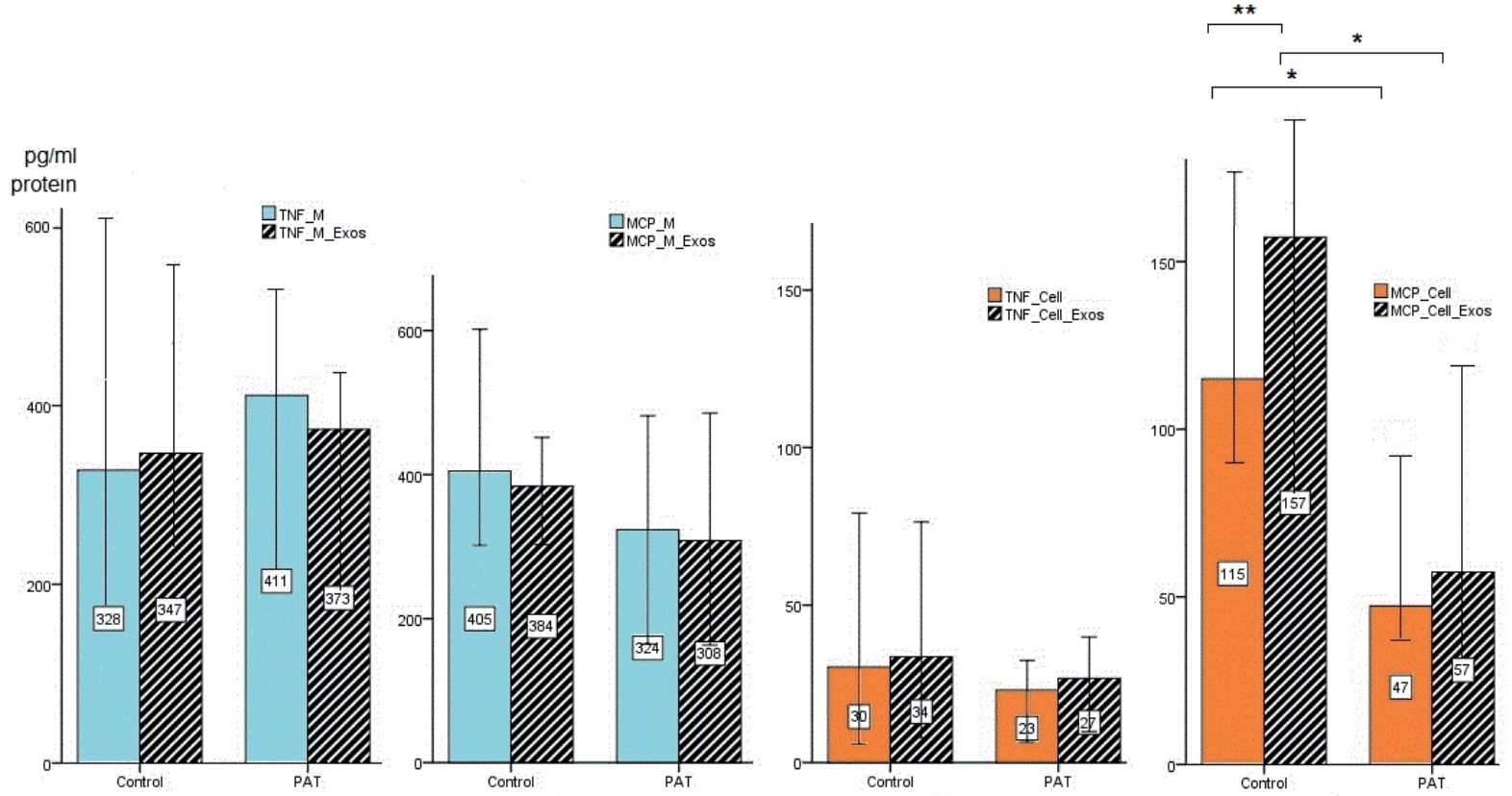

Fig. 2. Cytokine content: TNF $\alpha$ and MCP-1 in culture medium (M) and lysates of activated blood mononuclear cells (Cell) at baseline and after incubation with exosome suspension (M_Exos, Cell_Exos) in groups of healthy donors (Control) and patients (PAT). * - the difference between the corresponding indicators in the groups $\mathrm{P}<0.05$. $* *$ - difference under the influence of exosomes $\mathrm{P}<0.05$ 
significantly at baseline and under the influence of exosomes. The TNF $\alpha$ content in the control group was insignificaly higher compared to the PAT group. Incubation with exosomes slightly increased the TNF $\alpha$ content in both groups. In Cell samples of the control group MCP-1 was synthesized 2.4 times more $(\mathrm{P}<0.05)$ compared to the "PAT"group. Incubation with exosomes increased the content of MCP-1 in healthy donors by $26 \%(\mathrm{P}<0.05)$, therefore, under the regulatory influence of the exosomes the difference between the groups increased by 2.7 times. It should also be noted, that the content of interleukin MCP-1 in Cell samples of both groups was almost three times higher than the cytokine TNF $\alpha$ in absolute values.

Inthefollowing, we analyzed the gender differences of paracrine cytokine secretion in activated leukocytes (Fig. 3) and found unexpected gender differences, especially in patients.

$\mathrm{TNF} \alpha$ secretion in the control group in Medium did not have significant gender differences. Among patients, TNF $\alpha$ secretion in Medium was 2.7 times higher $(\mathrm{P}<0.05)$ in women than
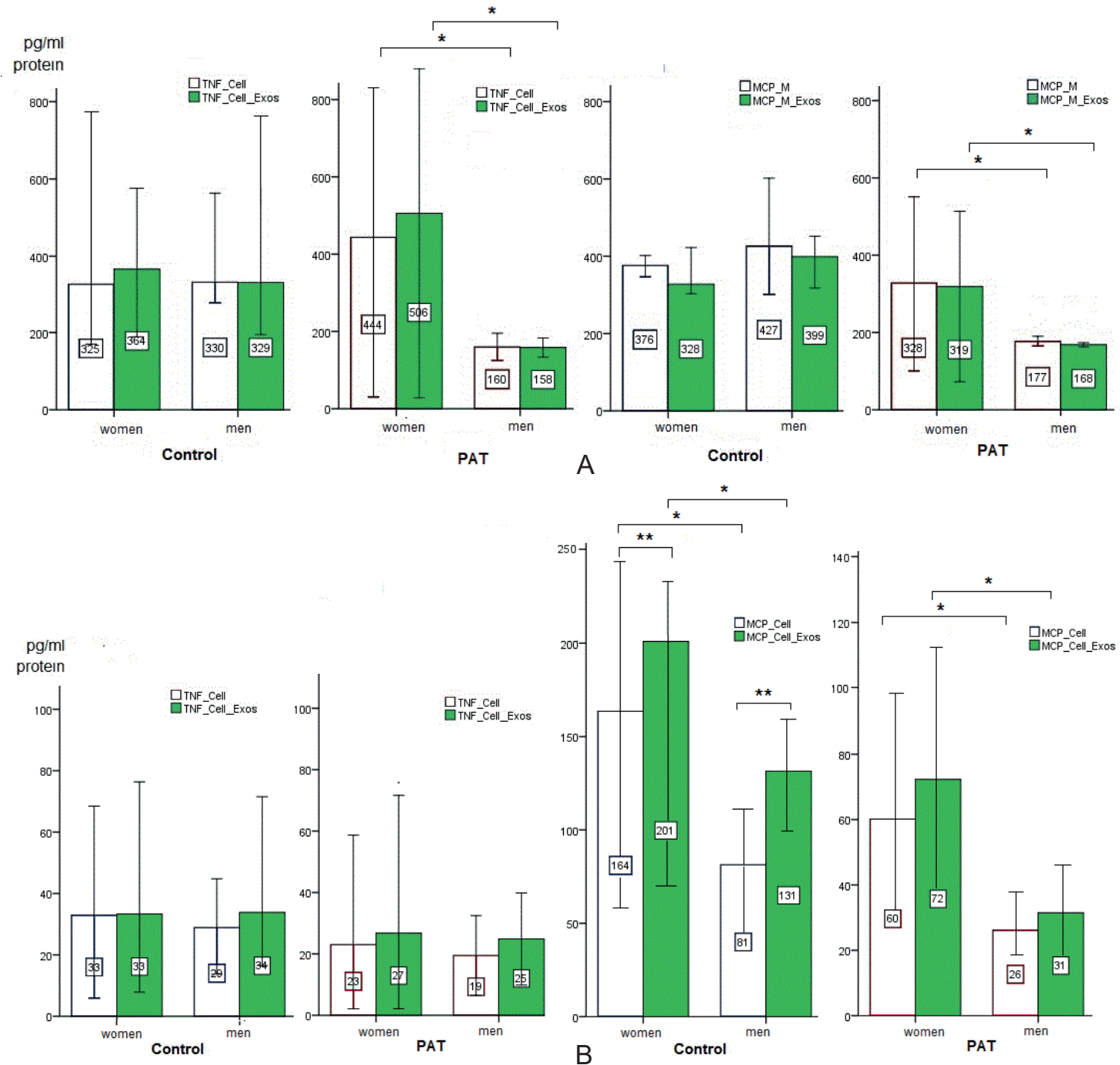

Fig. 3. Gender-associated differences in the level of cytokines TNF $\alpha$ and MCP-1 in the culture medium M (A) and lysates of activated blood mononuclear cells Cell (B) at baseline and after incubation with a suspension of exosomes (Exos) in women and men in groups healthy donors and patients. * - the difference between the corresponding indicators in the groups $\mathrm{P}<0.05$. ** - difference under the influence of exosomes $\mathrm{P}<0.05$ 
in men. Comparison with the control group in gender subgroups demonstrated, that in female patients paracrine secretion of TNF $\alpha$ in Medium was $26 \%$ more controlled and in male patients on the contrary twice less $(\mathrm{P}<0.05)$. Incubation with exosomes caused a slight increase in TNF $\alpha$ secretion in Medium samples only in women of both groups. The secretion of MCP-1 in Medium in the control group also did not have significant gender differences. Among patients, the secretion of MCP-1 in Medium was 1.8 times higher $(\mathrm{P}<0.05)$ in women than in men. In comperison with the control group, the paracrine secretion in female patients did not differ significantly from the control, and in male patients it was 2.4 times lower $(\mathrm{P}<0.05)$ than in healthy donors. Incubation with exosomes caused a slight decrease in MCP-1 secretion in Medium samples of the control group of both genders.

The synthesis of TNF $\alpha$ in Cell samples did not reflect significant gender differences. In patients the content of TNF $\alpha$ in Cell was reduced in comparison with control by $17-30 \%$. Incubation with exosomes caused a slight increase in cytokine production, especially in men of both groups. The synthesis of MCP-1 in Cell samples hadthe significant gender difference. In both groups the cytokine content in women was 2 times higher $(\mathrm{P}<0.05)$ than in men. Incubation with exosomes in the control group significantly increased the synthesis of MCP-1 in Cell - women by $18 \%$, men by $38 \%(\mathrm{P}<0.05)$. Incubation with exosomes in patients increased the synthesis of MCP-1 in Cell samples - in women by $16 \%$, men by $19 \%$.

Comparison with the control group in the gender subgroups demonstrated, that the content of MCP-1 in Cell female patients was 2.7 times lower $(\mathrm{P}<0.05)$ than in the women of control group. In male patients, the content of MCP-1 in Cell was 3 times lower $(\mathrm{P}<0.05)$ than in control. Under the influence of exosomes the synthesis of MCP-1 in Cell samples in women of the control group was 2.7 times higher than in female patients $(\mathrm{P}<0.05)$, and male cytokine synthesis was 4 times higher than in male patients $(\mathrm{P}<0.05)$.

The secretion of TNF $\alpha$ in the serum of the control group and the group "PAT" differed significantly, moreover - had gender differences (Fig. 4). In women of the control group and in women patients the cytokine content was 3
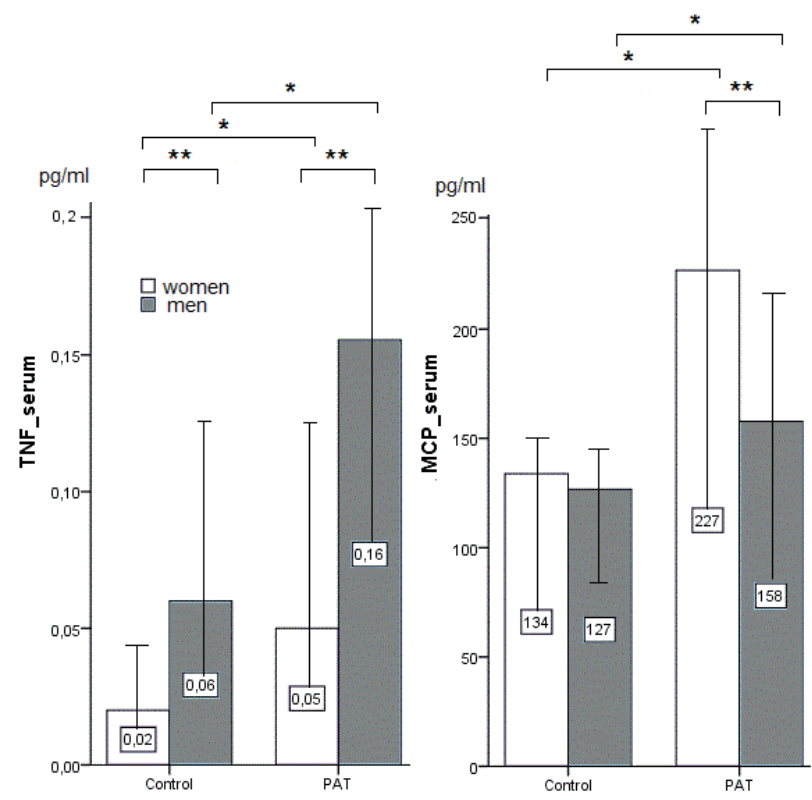

Fig. 4. Gender-associated differences in the serum content of TNF $\alpha$ and MCP-1 in women and men in the groups of healthy donors and patients. * - the difference between the corresponding indicators in the groups $\mathrm{P}<0.05$. ** - difference in the group $\mathrm{P}<0.05$ 
times lower than in men $(\mathrm{P}<0.05)$. In patients of both sexes the content of TNF $\alpha$ in serum was 2.5 times higher $(\mathrm{P}<0.05)$ than in the control. Secretion of MCP-1 in the serum of the control group was 1.2-1.7 $(\mathrm{P}<0.05)$ times lower than in patients. Gender differences were observed only in the group of patients, where women had a cytokine content 1.4 timeshigher $(\mathrm{P}<0.05)$ than in men.

The study of the exosomes influence on the synthesis and secretion of cytokines (important mediators of intercellular communications in the normal condition and in CHF) opens the prospect of the paracrine activity regulation of these compounds. By their properties, cytokines are short-range molecules, that act in low concentrations and mainly locally. Therefore, the manifestation of endocrine (remote) effect is possible only with their strong synthesis and intense secretion: due to the large number of cellular targets, the effect of cytokines is mainly pleiotropic [1].

The study demonstrated, that LPS-induced peripheral blood mononuclear cells demonstrate high paracrine secretion of the cytokine TNF $\alpha$. Already after a day of cells incubation the index of the ratio M/Cell is 13.3 c.u. (Fig. 5). The presence of CHF in patients increases the intensity of paracrine secretion of TNF $\alpha$ to values of M/Cell 18.0 c.u. Incubation of PBMC with exosomes of healthy donors leads to a decrease in $\mathrm{TNF} \alpha$ secretion, and thus, the $\mathrm{M} / \mathrm{Cell}$ index in patients decreases to the control level of 13.27 c.u.A special feature of paracrine TNF $\alpha$ secretion in patients with $\mathrm{CHF}$ was a gender-related difference: there was an increase in cytokine content in Medium samples of women compared to male patients and compared to women in the control group (Fig. 4). The presence of exosomes did not significantly influenced on cytokine secretion. At the same time, in the serum of patients with $\mathrm{CHF}$, the content of TNF $\alpha$ was significantly 3 times higher than in the control, but was more pronounced in men with CHF.

The multifunctional proinflammatory interleukin TNF $\alpha$ by its biological action is a molecular mediator in the reactions of natural immunity. Among other things, it plays a communicative role between the main phagocytes - granulocytes and macrophages. The increase in its serum level on the background of chronic inflammation, including heart failure, is

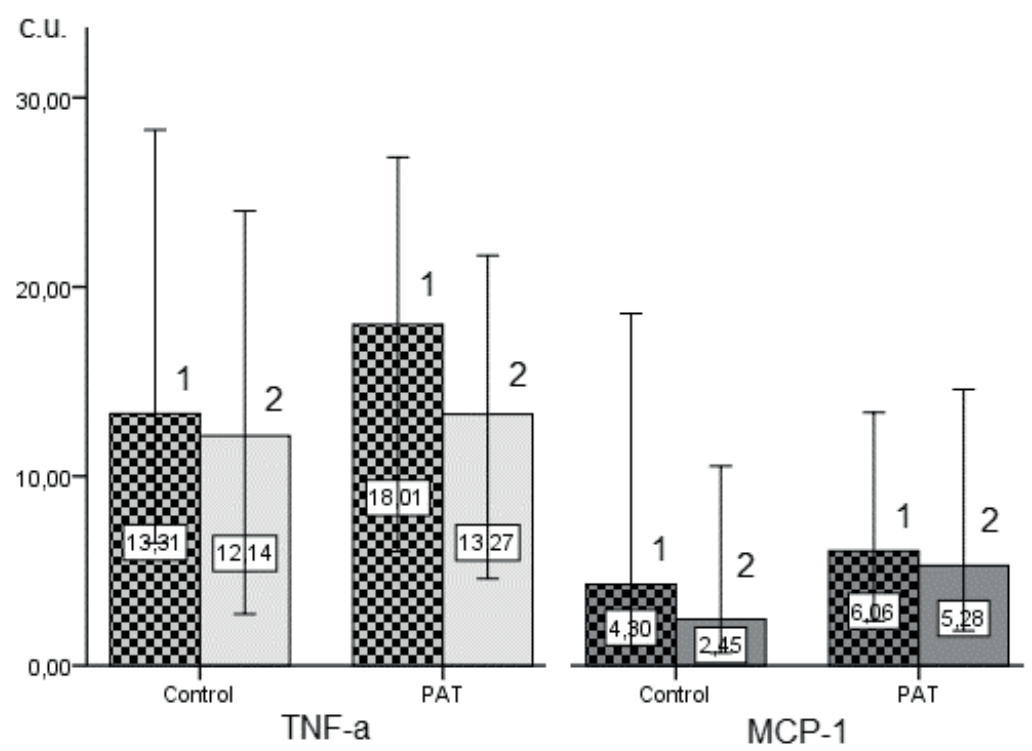

Fig. 5. The ratio of Medium/Cell cytokines contentat a basic level (1) and after incubation with exosome suspension (2) in the groups of healthy donors (Control) and patients (PAT). Calculated median and CI 95\% 
a well-known fact.

According to the results of our studies, the content of TNF $\alpha$ in the blood serum was at $10^{4}$ times lower than in Medium, while in Cell it was one order of magnitude lower than in Medium. Moreover, the synthesis of TNF $\alpha$ in activated leukocytes of patients and healthy people is almost the same. The level of cytokine on the background of CHFincreases only in Medium. Therefore, we can assume, that its paracrine and autocrine effects on cells are extremely powerful and are used by the body mainly for local intercellular communication.

The study revealed clear gender differences in the serum content of TNF $\alpha$ with its increase in men of both groups. At the same time, the rate of paracrine secretion of TNF $\alpha$ in Medium differed by gender only in patients and was manifested in a 3 -fold increase in its content in the group of women. Such gender differences suggest, that the endocrine potential of sex hormones may have a significant regulatory influence on the paracrine secretion of cytokines by PBMC cells. Convincing evidence suggests, that exogenous estrogen may activate mesenchymal stem cells (MSCs) through the estrogen receptor alpha, affecting the differentiation of MSC, thereby activating cyclin-dependent protein kinases, in particular MAPK (Mitogen activated protein kinases). These kinases mediate the proliferative effect of estrogen on embryonic cells [12, 13]. The study authors demonstrated a 3-fold increase in TNF $\alpha$ secretion by activated MSCs cells in male mice in comparison with females, interpreting this as a manifestation of hormonedependent anti-inflammatory, proliferative and regenerative activity in females.

Another study discusses the effect of androgen receptors (AR) on the therapeutic use of bone marrow mesenchymal stem cells (BMMSCs) in mice with liver cirrhosis [14]. Mice with overexpression of AR are shown to improve the efficiency of BM-MSC transplantation in the treatment of liver cirrhosis by enhancing the local paracrine effect, anti-inflammatory and antifibrotic action. Thus, there is no consensus on the effect of androgen and estrogen receptors on the features of paracrinecytokines secretion by peripheral blood cells and research in this promising area is actively continuing.

According to our results, incubation of PBMC cells of patients with exosomes suspension resulted in a decrease in paracrine secretion of $\mathrm{TNF} \alpha$ into the culture medium (Fig. 6). Probably, this effect can be defined as protective, because the previously observed effect of inhibitionof the proinflammatory cytokinessynthesis under the therapeutic influence of MSCs is known both in vitro and in vivo and has obvious signs of anti-inflammatory action [1].

The mechanism of induction of proinflammatory cytokines paracrine secretion in response to LPS stimulation is well known because $E$. coli lipopolysaccharides interact with Toll-like receptors on the cell surface and through a number of transcription factors (including NF-kB - nuclear factor kappa-b) in the nucleus carry out transcriptional regulation genes of the corresponding cytokines [15]. The effect (epigenetic factor) on cytokine synthesis can be represented as inhibition of intracellular expression in the posttranscriptional stage. This notion seems reasonable because, according to modern notions of exosomes, they are represented as transport intracellular vesicles with regulatory molecules of mRNA, microRNA, DNA fragments and enzymes. They have the potential to influence on the expression of certain target genes by regulating of transcription or RNA interference $[2,3,16]$.

The most interesting was the study of secretion by activated PBMC cells of the chemokine MCP-1. It is a potent chemoattractant cytokine, that is involved in paracrine and autocrine mechanisms of granulocyte-macrophage cell activation during the development of inflammatory reactions. We revealed, that cytokine synthesis in LPS-induced peripheral blood mononuclear cells is activated, but with a significant accumulation of it in cells. The $\mathrm{M} / \mathrm{Cell}$ ratio index in the control is $4.8 \mathrm{c} . \mathrm{u}$., which is three times less than a similar TNF $\alpha$ secretion rate. Moreover, 
in patients with $\mathrm{CHF}$, the synthesis of MCP-1 is significantly reduced compared to healthy donors, with a significant reduction in its cells content compared to the culture medium. So, the ratio $\mathrm{M} / \mathrm{Cell}$ is $6 \mathrm{c.u}$. Incubation of PBMC with exosomes increased the synthesis and accumulation of MCP-1 in cells, especially in the control group. Therefore, paracrine secretion of MCP-1 decreased under the influence of exosomes suspension in the control group by $43 \%$ and in the group "PAT" only by $17 \%$.

Other studies have showninhibition of MCP-1 synthesisand inhibition of lymphocyte activity after incubation with a MSCsmedium through the production of TGF-beta (Transforming growth factor beta) $[17,18]$. This effectthe authors consider as an anti-inflammatory impact of stem cells.

Our studies represent, that the chemoattractive properties of monocytes decrease under the influence of exosomes not due to a decrease in cytokine synthesis, but due to a decrease in the paracrine secretion of molecules into the extracellular space. This may also be an additional mechanism of "restraint" of inflammation.

Given that the CHFcondition reduces the synthesis of MCP-1 in PMBC cells, it should be assumed, that this cytokine under physiological conditions plays a regulatory role in ensuring intercellular communication in the granulocytemacrophage pool of various tissues, including blood. So, under the influence of an exosomes suspension this potential for cell communication increases, which is also inherent in the cells of a healthy body and can be positively correlated with the endocrine potential of sex hormones (androgen and estrogen receptors). Genderassociated differences in the development of $\mathrm{CHF}$ are the subject of current research. It is believed, that males have a much higher correlation with the development of myocardial ischemia [19], and the development of CHF in women is associated with hypertension, obesity and other factors. It is possible, that women have additional physiological adaptive mechanisms for preventing the development of inflammation.
Moreover, it is likely, that exosomes enhance such mechanisms. In the case of decompensation and increased secretion of MCP-1, the serum content of cytokines increases. As we found in patients with $\mathrm{CHF}$, to a greater extent it is manifested in women.

According to our data, the synthesis and accumulation of MCP-1 in leukocytes of healthy donors increasedunder the exosomes influence by $26 \%(\mathrm{P}<0.05)$, while in women by $18 \%(\mathrm{P}<$ $0.05)$, in men by $38 \%(\mathrm{P}<0.05)$, Figure 4 . Incubation with exosomes of patients' cells increased the intracellular synthesis of MCP-1 - in women by $16 \%$, men by $19 \%$. As a result, the synthesis of MCP-1 under theexosomes influence in the activated cells of women in the control group was higher than in female patients by 2.7 times $(\mathrm{P}<0.05)$, and men by 4 times $(\mathrm{P}<0.05)$ than in male patients

Thus, under the influence of exosomes the content of cytokine MCP-1 in cells increases, but its paracrine secretion decreases. This may also be a manifestation of the physiological mechanism of "restraint" of inflammation.

The synthesis of TNF $\alpha$ in activated leukocytes of patients and healthy people is almost the same. On the background of CHF, the level of cytokine increases only in Medium, which indicates a significant role of interleukin TNF $\alpha$ in local intercellular communication and significant endocrine remote influence. Incubation with exosomes did not cause a significant change in cytokine production.

\section{CONCLUSIONS}

Therefore, the study in vitro of the exosomes influence of healthy donors on paracrine secretion of PBMC cells of healthy people and $\mathrm{CHF}$ patients reflected certain features and differences, determined by the type of target cytokine, intensity of its synthesis, their accumulation in the cell and gender-related differences.

The synthesis of TNF $\alpha$ in activated leukocytes of patients and healthy subjectswas almost the 
same. On the background of CHF the level of this cytokine increases only in Medium. Significant gender-associated changes of TNF $\alpha$ level in the PBMC medium of the CHF patient group and exosome-related decrease in its paracrine secretion may indicate a critical role of this cytokine in local intercellular communication as well as its accented contribution in the formation of endocrine remote communication, especially in conditions of chronic inflammation.

The content of MCP-1 in activated leukocytes of patients decreased by 3 times and was followed by a significant gender-associated difference. In addition, a significant effect on the change in the MCP-1 content was determined by incubation with anexosomes suspension: synthesis and accumulation of MCP-1 in the leukocytes of healthy donors increased and was followed by gender-associated differences.

Under the influence of exosomes, the level of cytokine MCP-1 in cells increases, but its paracrine secretion into the culture medium decreased. This demonstrated an inequality in the molecular action of interleukins MCP-1 and TNF $\alpha$, their secretion and sensitivity to the regulatory content of exosomes, including gender-associated factor.

These cytokine-adjusting effects endow the suspension of exosomes as such a potential therapeutic effect that perspectively may impact on the basic mechanisms of the development of endothelial dysfunction.

The authors of this study confirm that the research and publication of the results were not associated with any conflicts regarding commercial or financial relations, relations with organizations and/or individuals who may have been related to the study, and interrelations of co-authors of the article.

Acknowledgment. The authors thank Professor V.A. Chernyak for an idea of studying exosomes impact on the cytokine secretion in blood cells.

Funding. This work was supported by a research grant of the Ministry of Health of Ukraine (No. state registration 0119 U101218).
Л.В. Натрус ${ }^{1}$, П.Ф. Музиченко ${ }^{1}$, Д.О. Лабудзинський ${ }^{2}$, П.А. Черновол ${ }^{1}$, Ю.Г. Клись ${ }^{1}$

ВПЛИВ ЕКЗОСОМ НА ПАРАКРИННУ
СЕКРЕЦІЮ МОНОНУКЛЕАРІВ
ПЕРИФЕРИЧНОЇ КРОВІ ПАЦІСНТІВ
IЗ ХРОНІЧНОЮ СЕРЦЕВОЮ
НЕДОСТАТНІСТЮ

Дослідження впливу екзосом здорових донорів на паракринну секрецію мононуклеарних клітин периферичної крові їх та пацієнтів із хронічною серцевою недостатністю (ХСН) продемонструвало існування гендер-асоційованих змін у синтезі та секреції лейкоцитами ключових факторів запалення ендотелію судин. Показано, що під впливом екзосом підвищувався синтез i накопичення цитокіну МСР-1 (англ., Monocyte Chemoattractant Protein-1) у лейкоцитах здорових донорів на 26\%; при цьому у жінок на $18 \%$, у чоловіків на $38 \%$. Інкубація клітин пацієнтів із суспензією екзосом підвищувала внутрішньоклітинний синтез МСР-1 у жінок на 16\%, у чоловіків на 19\%. Цікаво, що в активованих клітинах жінок контрольної групи синтез МСР-1 під впливом екзосом був вище у 2,7 раза, ніж у жінок-пацієнтів, а у лейкоцитах донорів-чоловіків у 4 рази вище, ніж у пацієнтів чоловічої статі. Отже, під впливом екзосом синтез цитокіну МСР-1 в клітинах підвищується, але його паракринна секреція знижується, що можна розглядати як один із фізіологічних механізмів «стримання» розвитку запалення. Було показано, що рівень синтезу цитокіну фактора некрозу пухлин альфа (ФНП $)$ в активованих лейкоцитах пацієнтів та здорових осіб був майже однаковим, тоді як у групі з ХСН вміст ФНП $\alpha$ підвищувався лише в культуральному середовищі. Інкубація з екзосомами не спричинила значних змін у продукуванні цитокіну, але у групі з ХСН спостерігалася тенденція до зменшення індексу «середовище/клітина» більше ніж у 1,3 раза. Наша експериментальна робота демонструє потребу подальшого вивчення впливу екзосом на функції лейкоцитів периферичної крові як в експериментальних моделях in vitro, так і in vivo. Подальші дослідження коригуючих ефектів екзосом сприятимуть розробці алгоритмів потенційного терапевтичного впливу на механізми, які ініціюють запалення ендотелію i є головними фактороми розвитку гострої та хронічної ішемії.

Ключові слова: екзосоми; хронічна серцева недостатність; МCP-1; ФНП $\alpha$; паракринна секреція; гендерасоційовані відмінності.

${ }^{1}$ Національний медичний університет імені

О.О. Богомольия, Київ;

${ }^{2}$ Інститут біохімії ім. О.В. Палладіна НАН України, Kü̈в; e-mail: Lnatrus777@gmail.com 


\section{Л.В. Натрус, П.Ф. Музыченко, Д.О. Лабудзин- ський, П.А. Черновол, Ю.Г. Клысь \\ ВЛИЯНИЕ ЭКЗОСОМ НА ПАРАКРИННУЮ СЕКРЕЦИЮ МОНОНУКЛЕАРОВ ПЕРИФЕРИЧЕСКОЙ КРОВИ ПАЦИЕНТОВ С ХРОНИЧЕСКОЙ СЕРДЕЧНОЙ НЕДОСТАТОЧНОСТЬЮ}

Исследование влияния экзосом здоровых доноров на паракринную секрецию мононуклеарных клеток периферической крови у здоровых людей и пациентов с хронической сердечной недостаточностью $(\mathrm{XCH})$ продемонстрировало наличие гендерассоциированных различий в синтезе и секреции лейкоцитами ключевых факторов воспаления эндотелия сосудов. Было показано, что под влиянием экзосом повышался синтез и накопление цитокина МСР-1 (англ., Monocyte Chemoattractant Protein-1) в лейкоцитах здоровых доноров на $26 \%$; при этом у женщин на $18 \%$, у мужчин на $38 \%$. Инкубация клеток пациентов с суспензией экзосом повышала внутриклеточный синтез МСР-1 у женщин на $16 \%$, у мужчин на $19 \%$. Интересно, что в активированных клетках женщин контрольной группы синтез МСР-1 под влиянием экзосом был выше в 2,7 раза, чем у женщинпациентов, а в лейкоцитах доноров-мужчин в 4 раза выше, чем у пациентов мужского пола. Итак, под влиянием экзосом синтез цитокина МСР-1 в клетках повышается, но его паракринная секреция снижается, что можно рассматривать как один из физиологических механизмов «сдерживания» развития воспаления. Было показано, что уровень синтеза цитокина фактор некроза опухолей альфа $(\Phi H О \alpha)$ в активированных лейкоцитах пациентов и здоровых лиц был почти одинаковым, тогда как в группе с ХCH содержание ФНПа повышается только в культуральной среде. Инкубация с екзосомами не вызвала значительных изменений в выработке цитокинов, но в группе с ХCH наблюдалась тенденция к уменьшению индекса «среда/ клетка» больше чем в 1,3 раза. Наша экспериментальная работа демонстрирует необходимость дальнейшего изучения влияния экзосом на функции лейкоцитов периферической крови как в экспериментальных моделях in vitro, так и in vivo. Дальнейшие исследования корректирующих эффектов экзосом может быть основанием разработки алгоритмов терапевтического воздействия на механизмы, которые инициируют воспаление эндотелия и являются главными факторами развития острой и хронической ишемии.

Ключевые слова: екзосомы; хроническая сердечная недостаточность; МСР-1; ФНО ; паракринная секреция; гендерассоциированные различия.

\section{REFERENCES}

1. Khubutiya MS, Vagabov AV, Temnov AA, Sklifas AN. Paracrine mechanisms of proliferative, anti-apoptotic and anti-inflammatory effects of mesenchymal stromal cells in models of acute organ injury. Cytotherapy. 2014;16(5):579-85.

2. Kalluri R, LeBleu VS. The biology, function, and biomedical applications of exosomes. Science. 2020;367 (6478): eaau6977.

3. Raposo G, Stoorvogel W. Extracellular vesicles: exosomes, microvesicles, and friends. J Cell Biol. 2013;200(4):373-83.

4. Patel GK, Khan MA, Zubair H, Srivastava SK, Khushman M, Singh S, Singh AP. Comparative analysis of exosome isolation methods using culture supernatant for optimum yield, purity and downstream applications. Sci Rep. 2019;9(1):5335.

5. Théry $\mathrm{C}$, Witwer KW, Aikawa E, et al. Minimal information for studies of extracellular vesicles 2018 (MISEV2018): a position statement of the International Society for Extracellular Vesicles and update of the MISEV2014 guidelines. J Extracell Vesicles. 2018;7(1):1535750.

6. Fernando MR, Jiang C, Krzyzanowski GD, Ryan WL. New evidence that a large proportion of human blood plasma cell-free DNA is localized in exosomes. PLoS One. 2017;12(8): e0183915.

7. Liu M, Chen J, Huang D, Ke J, Wu W. A meta-analysis of proinflammatory cytokines in chronic heart failure. Heart Asia. 2014; 6(1):130-6.

8. Kotyla PJ. Bimodal function of anti-TNF treatment: Shall we be concerned about anti-tnf treatment in patients with rheumatoid arthritis and heart failure? Int J Mol Sci. 2018;19(6):1739. Published 2018 Jun 12.

9. Riedhammer C, Halbritter D, Weissert R. Peripheral blood mononuclear cells: isolation, freezing, thawing, and culture. Methods Mol Biol. 2016; 1304:53-61.

10. Klinder A, Seyfarth A, Hansmann D, et al. Front Immunol. 2018; 9:831.

11. https://www.abcam.com/protocols/elisa-sample-preparation-guide-1

12. Crisostomo PR, Wang M, Herring CM, et al Gender differences in injury induced mesenchymal stem cell apoptosis and VEGF, TNF, IL-6 expression: role of the $55 \mathrm{kDa}$ TNF receptor (TNFR1). J Mol Cell Cardiol. 2007; 42(1):142-9.

13. Yan L, Zheng D, Xu RH. Critical role of tumor necrosis factor signaling in mesenchymal stem cell-based therapy for autoimmune and inflammatory diseases. Front Immunol. 2018; 9:1658.

14. Huang CK, Lee SO, Lai KP, et al. Targeting androgen receptor in bone marrow mesenchymal stem cells leads to better transplantation therapy efficacy in liver cirrhosis. Hepatology. 2013; 57(4):1550-63.

15. Ambrozova N, Ulrichova J, Galandakova A. Models for the study of skin wound healing. The role of NRF2 and NF-KB. Biomed Pap Med Fac Univ Palacky Olomouc Czech Repub. 2017;161(1):1-13.

16. Witwer KW, Théry C. Extracellular vesicles or exosomes? On primacy, precision, and popularity influencing a choice of nomenclature. J Extracell Vesicles. 2019; 8(1):1648167. 
17. Groh ME, Maitra B, Szekely E, Koç ON. Human mesenchymal stem cells require monocyte-mediated activation to suppress alloreactive T cells. ExpHematol. 2005; 33(8):928-34.

18. Tesarova L, Jaresova K, Simara P, Koutna I. Umbilical cord-derived mesenchymal stem cells are able to use bFGF treatment and represent a superb tool for immunosuppressive clinical applications. Int J Mol Sci. 2020;21(15):5366.

19. Azad N, Kathiravelu A, Minoosepeher S, et al Gender differences in the etiology of heart failure: A systematic review. J Geriatr Cardiol. 2011; 8(1):15-23.

Received 18.09.2020 